\title{
STRES U PROFESIONÁLNÍCH ŘIDIČŮ SE ZAMĚŘENÍM NA ŘIDIČE AUTOBUSŮ, PREVENTIVNÍ OPATŘENÍ A PROTISTRESOVÉ PROGRAMY
}

\author{
Miroslava Horáková
}

\begin{abstract}
Abstrakt
Povolání profesionálního řidiče patří mezi vysoce stresující zaměstnání s negativními dopady na zdravotní a psychickou stránku. Řidič je denně vystaven celé řadě náročných požadavků a stresorů, se kterými se musí vyrovnávat. Situace vyrovnávání se se stresem při řízení je popisována pomocí transakční teorie řidičského stresu spolu s copingovými strategiemi při řízení, které mají vliv na kvalitu řízení, a jejichž identifikace a náprava ukazují na možnosti intervence. Důležitou skupinou profesionálních řidičů jsou řidiči autobusů. Významnými stresory pro tyto řidiče jsou časový tlak, nadměrná pracovní zátěž, vysoká environmentální stimulace, problematická interakce s dalšími účastníky dopravního provozu, nedostatek sociální opory a nepravidelné směny. Mezi nejdůležitější preventivní opatření na snížení míry stresu patří eliminace nebo modifikace situací vytvářejících stres, přizpůsobení organizace práce individuálním charakteristikám řidičů a posílení osobní odolnosti řidičů vůči stresu. Jsou zde uvedeny některé konkrétní př́klady realizovaných programů, ve kterých jsou použity principy vedoucí ke snížení míry stresu u těchto řidičůn, zvýšení životní pohody a snížení negativních zdravotních důsledků.
\end{abstract}

Klíčová slova: řidičský stres, coping, profesionální řidič, řidič autobusu, protistresové programy

\section{STRESS AMONG PROFESSIONAL DRIVERS, WITH FOCUS ON BUS DRIVERS, PREVENTIVE STRATEGIES AND ANTI-STRESS PROGRAMS}

\begin{abstract}
The group of professional drivers belongs to high demanding jobs with high risks in health status and psychical wellbeing. Drivers are daily exposed to high demands and stressors they have to face. The situation of coping with stress is described by the transactional model of driver stress and coping strategies while driving. These strategies influence driving performance and their identification could be one of the possible interventions for stress reduction. This study focuses on the group of bus drivers, which is a significant subgroup of professional drivers. The main stressors for them are time pressure, high work demands, high environmental stimulation, problematic interactions with other road users, lack of social support and irregular shifts. The most important preventive strategies are elimination or modification of stress-producing situations, the adaptation of work organization to the individual characteristics of the driver and strengthening the driver's resilience to stress. We describe some programs using the principles of stress reduction by professional drivers, which increase wellbeing and decrease negative health consequences.
\end{abstract}

Keywords: driving stress, coping, professional driver, bus driver, anti-stress programs

Došlo: 7. 10. 2019

Schváleno: 25. 2. 2020 


\section{Úvod}

Problematika řidičského stresu je se zvyšující se hustotou dopravy aktuální téma, které má řadu souvislostí a důsledků. Ř́zení automobilu je v mnoha situacích vysoce stresující činnost, zejména u profesionálních řidičů. $\mathrm{V}$ předloženém článku se snažíme podat podrobný přehled týkající se této problematiky. V první části příspěvku se obecně věnujeme řidičskému stresu a copingovým strategiím, v druhé části podrobně rozpracováváme specifika stresu u jedné skupiny profesionálních řidičů a v části poslední shrnujeme možné intervence a preventivní protistresové programy pro tuto skupinu řidičů. Studie se zaměřuje především na skupinu řidičů autobusů, tedy na řidiče, kteří jsou při své každodenní činnosti v kontaktu s pasažéry a v důsledku toho disponují vysokou mírou zodpovědnosti za lidské životy. Cílem je popsat míru stresové zátěže u těchto řidičů a podat přehled o možných preventivních opatřeních. Tato studie tematicky navazuje na příspěvek publikovaný v jednom z predchozích čísel časopisu „E-psychologie“" (Horáková, 2009), v jehož úvodu jsme shrnuli teorie stresu a základním způsobem popsali problematiku řidičského stresu. $\mathrm{V}$ posledních několika letech nebylo tomuto tématu věnována dostatečná pozornost, proto je aktuálně potřeba tuto problematiku podrobněji rozpracovat a posunout dále.

\section{Stres v dopravě}

Stres v dopravě je definován jako jakákoli zátěž související s řízením motorového vozidla, která vede k nutnosti se s ní vyrovnávat a může mít negativní vliv na prožívání a chování řidiče. V prŕṕpadě nadlimitní zátěže vzniká stresová reakce se svými negativními fyziologickými důsledky a ovlivněním chování, přičemž na jejím vzniku se podílí celá řada charakteristik - roli hrají např. vnější okolnosti dopravní situace (hustý provoz, dopravní zácpa, složitá dopravní situace aj.), osobnostní vlastnosti řidiče (např. míra neuroticismu a psychická odolnost) a kognitivní procesy řidiče (Matthews, 2002). Působící stresory souvisejících s řízením tak ovlivňují řidičský výkon a jsou faktorem přispívajícím k nižšśi dopravní bezpečnosti.

\section{Teorie řidičského stresu}

Z obecných teorií stresu pokrývajících vznik stresové reakce lze zmínit Lazarusovu transakční teorii stresu (Lazarus, 1966; Lazarus \& Folkman, 1984), která vznik stresové reakce spojuje s kognitivním hodnocením, při němž jedinec posoudí danou situaci tak, že nemá dostatek zdrojů pro její zvládnutí. Je patrné, že tato teorie problematiku stresu v dopravě pokrývá jen zčásti, a proto byl proveden rozsáhlý výzkum stresu při řízení (např. Matthews 1996, 2001, 2002; Matthews et al., 1998), na jehož základě byl vyvinut detailní rámec řidičského stresu založeného na transakčním prŕístupu. Matthewsův transakční model (2002) zahrnuje několik faktorů: environmentální stresory specifické pro řidičské prostředí (např. špatné počasí, dopravní zácpa); kognitivní procesy stresu (hodnocení vnějších požadavků, volba copingové strategie), které generují projevy stresu; osobnostní rysy (např. agresivita, nechut' k řízení) spojené se zranitelností vůči řidičskému stresu; subjektivní symptomy (napřr. únava, apatie, tenze, starosti) a ovlivněný výkon (např. ztráta pozornosti, riskování). Mezi charakteristiky, které jsou zdrojem pro kognitivní procesy stresu, patří environmentální stresory a osobnostní faktory. Vznikající stresová reakce se pak projevuje voblasti konkrétních subjektivních 
symptomů a řidičského výkonu (Matthews, 2002). Z výše uvedeného je patrné, že lze předpokládat, že někteří řidiči budou mít vyšší tendenci reagovat v zátěžové situaci maladaptivně, a to na základě vrozených osobnostních predispozic, ale i v souvislosti s tím, jakým způsobem jsou zvyklí situace vyhodnocovat a reagovat na ně. Nezanedbatelný vliv má i situace a okolnosti řízení, které představují míru působící stresové zátěže, se kterou se musí řidič vyrovnat.

\section{Copingové strategie}

V souvislosti s pojmem stres je třeba zmínit tzv. coping, což je způsob, jakým se lidé vyrovnávají se stresem. Jedná se o specifické způsoby přistupu ke stresu (tzv. strategie zvládání stresu), jejichž cílem je minimalizovat působící stres nebo konflikty. Identifikace jednotlivých copingových stylů přináší možnost nácviku jejich efektivních variant. Pojem coping se vyskytuje i v souvislosti s řízením a je klíčový pro vytvoření adaptivních způsobů zvládání stresu souvisejícího s řízením. Matthews, Desmond, Joyner, Carcary a Gilliland (1996) identifikovali 5 copingových stylů při řízení (zjišt'ovaných pomocí dotazníku DCQ - Driving coping questionnaire): konfrontativní coping (např. uvolnění vlastního napětí riskováním nebo napadání ostatních řidičů), coping zaměřený na zvládání úkolů (napřs. snaha jet bezpečně a dodržovat pravidla), coping zaměřený na emoce (např. sebekritika, starosti, sebeobviňování), coping přehodnocení (pozitivní „přeznačkování“ situace - např. vnímat jízdu jako něco hodnotného nebo jako proces získávaní zkušeností) a vyhýbavý coping (např. myslet na něco jiného, v situaci se nijak neangažovat, potlačit negativní emoce). Mathews et al. (1996) ve svém výzkumu shrnují, že „konfrontativní“ a „na emoce zaměřený“ coping patří mezi maladaptivní copingové strategie spojené s negativními důsledky. Uvádí, že „konfrontativní“ coping způsobuje projevy násilí, chyby a ztrátu bezpečí a coping „zaměřený na emoce“ může potenciálně vést $\mathrm{k}$ distrakci pozornosti řidiče, která negativně ovlivňuje kognitivní funkce související s řízením. Strategie „přehodnoceni““ může naopak přinést pozitivní využití řidičských zkušeností. V rámci výzkumu se ukazuje, že coping ,zaměřený na zvládání úkolu“ a „přehodnocení“ patří mezi nejvíce adaptivní strategie, zatímco „konfrontativní“ coping a coping „zaměřený na emoce“ mezi nejvíce maladaptivní (Matthews et al., 1996). Mezi důsledky maladaptivního copingu patří odklon pozornosti od úkolu spojený s únavou, demotivací a ztrátou koncentrace (Matthews \& Desmond, 1998), distres projevující se jako negativní afektivita včetně tenze, vzteku, ztráty radosti a nedostatku sebejistoty (Matthews, 2002) a starosti definované jako negativní myšlenky, které mohou ovlivňovat pozornost (Sarason et al., 1986).

Matthews (2002) určil 5 osobnostních faktorů (zjišt’ovaných pomocí dotazníku DSI - Driving stress inventory) způsobujících zvýšenou náchylnost k řidičskému stresu, kterými jsou: agrese, negativní vztah k řízení, monitorování hazardu, dosahování vzrušení a náchylnost k únavě. „Agrese“ souvisí s pocity vzteku, netrpělivosti, hostility a negativním přesvědčením o ostatních; „negativní vztah k řízení“ je spojený s pocity úzkosti, strachem z nehody a napětím např. při předjíždění a negativním hodnocením vlastních řidičských schopností; „monitorování hazardu“ souvisí s ostražitostí k nebezpečí, snahou vyhnout se riziku a jezdit bezpečně; „dosahování vzrušeni'“ znamená tendenci podstupovat nebezpečí za účelem vlastního potěšení, 
např. rychlá jízda nebo riskantní manévry; „náchylnost k únavě“ je popisována jako tendence $\mathrm{k}$ unavitelnosti při delším řízení a súnavou související zhoršování řidičského výkonu (Matthews, 2002). Lze shrnout, že řidiči, kteří mají predispozice k stresové reakci, jezdí méně bezpečně, protože jejich řidičský výkon je negativně ovlivněn. Lidé s „negativním vztahem k řízení" vykazovali zhoršení řidičských schopností a nižší kontrolu nad vozidlem (např. v jízdě mezi dalšími vozidly, v plynulosti jízdy, při předjíždění), měli sníženou pozornost a horší náladu; ,agrese“ vedla k vysoké rychlosti, riskantnímu předjíždění a chybám při něm; vysoká míra „bdělosti“ pomáhala k rychlejšímu rozpoznání chodců a tím k jejich bezpečnosti (Matthews et al., 1998).

Osobnostní charakteristiky související s odolností vůči stresu a copingové strategie hrají u profesionálních řidičů velkou roli, protože mají vliv na duševní pohodu řidičů, jejich zdravotní stav a míru nehodovosti. Stres a řidičská únava nejsou pouhým důsledkem hodin strávených za volantem, ale vznikají v souvislosti s typem jízdy, organizací práce, efektivitou procesů týkajících se pasažérů a přepravovaného zboží, duševní pohodou řidičů, jejich zdravím a strategiemi, které použivají pro zvládání nečekaně se vyskytnuvších obtíží (Machin, 2001). Mathewsův transakční rámec řidičského stresu byl využit k vysvětlení stresu a únavy nejen u běžných řidičů, ale byl aplikován i u specifických skupin řidičů, jako jsou např. řidiči autobusu. Machin a Hoare (2008) provedli výzkum na 159 australských řidičích autobusu s cílem zjistit rozsah, v jakém pracovní zátěž a řidičské copingové styly predikují subjektivní zdravotní stav. Zkoumali, nakolik jsou zdraví a psychická pohoda těchto řidičů ovlivněny pracovními požadavky a copingovými strategiemi. Předpokládali, že řidiči používající adaptivní strategie a méně maladaptivních strategií budou vykazovat menší potřebu odpočinku, více pozitivních afektů, méně negativních afektı̊ a méně fyzických symptomů. Model zahrnoval několik faktorů: počet hodin strávených řízením jako ukazatel pracovní zátěže, adaptivní a maladaptivní copingové styly, výpovědi o potřebě odpočinku, pozitivní a negativní afekty a fyzické symptomy. Výsledky odhalily, že pracovní zátěž byla signifikantním prediktorem řidičovy potřeby odpočinku. Dvě maladaptivní copingové strategie (,konfrontativní“" coping a coping ,zaměřený na emoce“) vedly ke zvýšené potřebě odpočinku a negativní afektivitě. Adaptivní copingová strategie „přehodnocení“ prřspívala k pozitivní afektivitě (Machin \& Hoare, 2008). Dorn, Stephen, Wahlberg a Gandolfi (2010) v této souvislosti zjistili ve svém výzkumu na 315 britských řidičích autobusu, že dvě maladaptivní copingové strategie (coping „zaměřený na emoce“ a „vyhýbavý“ coping) vedly pod časovým tlakem k zhoršení řidičského výkonu. Autoři doporučují identifikovat u řidičů rizikové copingové styly jakožto možné prediktory rizikového řidičského chování a navrhnout adekvátní preventivní opatření.

Kühlmann (1990) provedl dotazníkové šetření týkající se zvládání stresu u 99 německých řidičů městských autobusů a tramvají. Faktorová analýza ukázala 4 faktory copingu: mentální snaha po podpoře sebe sama (pozitivní sebeinstrukce), rezignovaného podř́zení se situaci s tendencí k agresivnímu emočnímu vybití (nestabilní submise), odklon pozornosti k jiným věcem (popření), rozhodnutí poučit se z minulosti a vytvořit plán na vyhnutí se stresující události do budoucna (aktivní prevence). Řidiči preferovali zmírňující mentální procesy (např. podpora sebe sama, zmírnění tlaku na sebe) a také snahy o řešení problému; méně často uváděli 
rezignované přijetí a emoční vybití. U těch řidičů, kteří používali kombinaci rezignovaného podřízení se situaci s emočním vybitím, byla větší tendence k prožívání pracovního stresu, horšímu zdravotnímu stavu, pocitům vyčerpání po pracovním dni a potřebě delšího času $\mathrm{k}$ rekreaci.

Právě identifikace použivaných copingových strategií a nácvik jejich adaptivních verzí je z našeho úhlu pohledu vhodným nástrojem $\mathrm{k}$ tomu, jak lze pozitivním způsobem ovlivňovat řidiče z povolání směrem $\mathrm{k}$ jejich vyšší odolnosti ve stresových situacích. Lze předpokládat, že řidiči, kteří si uvědomí svoji tendenci využívat negativní copingové strategie, jež vedou k prohloubení stresové reakce, se mohou naučit používat vhodnější strategie, které mají ve svém důsledku zvýšení jejich psychického komfortu a bezpečného dopravního chování. Příklad jednoho z preventivních programů na identifikaci a reedukaci copingových stylů je uveden v závěru této studie. V této souvislosti by bylo žádoucí u profesionálních řidičů využívat dotazník copingových stylů př̀ řízení, který však zatím není v českém jazyce k dispozici, a proto by bylo na zvážení jeho převzetí ze zahraničních zdrojů.

\section{Profesionální řidiči a stresová zátěž (se zaměřením na řidiče autobusů)}

Profesionální řidiče lze zařadit mezi vysoce stresující profese. Dle výzkumů patří tito řidiči mezi skupinu zaměstnanců, kteří mají nejvyšší výskyt pracovně podmíněného stresu (Biggs, Dindag, \& Stenson, 2009). Toto povolání je hodnoceno jako zaměstnání s vysokými pracovními nároky, avšak nízkou mírou kontroly a možností ovlivnit situaci (Kompier, 1996). Dle Karaskova modelu (1979) pracovních požadavků a kontroly (model of jobs demand and control - JDC model) se v tomto př́padě projevují nepř́znivé reakce související s psychologickou zátěží, které spolu s nízkou sociální podporou mají negativní vliv na zdraví, duševní pohodu řidičů a pracovní výkon. Pracovní napětí (tzv. job strain), které v této souvislosti vzniká, se projevuje v podobě zdravotních obtíží a chronické únavy s obtížemi se spánkem (De Lange et al., 2009).

V rámci skupiny profesionálních řidičů lze vymezit skupinu řidičů autobusů, u nichž zvýšená zodpovědnost za lidské životy spolu s vysokými nároky silničního provozu a samotné profese znamená vyšší vystavení stresové zátěži. Jedná se o řidiče zaměstnané v dopravních podnicích a dalších firmách zajišt'ujících veřejnou přepravu osob. Konkrétně může být tato skupina řidičů rozdělena na řidiče autobusů městské dopravy, dopravy příměstské, event. regionální a řidiče dálkové dopravy (vnitrostátní a mezinárodní). Studie zkoumající stres u řidičů autobusů vykazují společné rysy: vysoké požadavky na řidiče, možnost nízké kontroly a nízká podpora, přičemž tato kombinace znamená stres a zvýšené riziko fyzického a mentálního onemocnění zapříčiněného zaměstnáním, který vede $\mathrm{k}$ absentismu a snížené produktivitě zaměstnanců a podniků (Kompier, 1996). Úskalím stresové zátěže je, že ovlivňuje řidičský výkon, a může tak snižovat bezpečné řidičské chování např. v podobě využívání potencionálně nebezpečných copingových strategií, jako jsou agresivní reagování na ostatní řidiče nebo odvádění pozornosti od řidičských úkonů (Dorn, Stephen, Wåhlberg, \& Gandolfi, 2010). 


\section{Hlavní stresory profese a jejich di̊sledky}

Významnými stresory profese řidiče autobusu jsou kontinuální časový tlak, nadměrná pracovní zátěž, vysoká environmentální stimulace, problematická interakce s dalšími účastníky dopravního provozu, nedostatek sociální opory a nepravidelné směny (Öz, Özkan, \& Lajunen, 2010). Mezi vysoké pracovní nároky patří faktory psychologické (vysoká míra koncentrace a pozornosti), sociální (interakce s pasažéry) a ty, co souvisejí se situací řízení (ovládání vozidla, bezpečné řízení a interakce s ostatními účastníky silničního provozu). Kompier (1996) shrnuje hlavní problémy spojené s profesí řidiče autobusů: 1. oblast práce - vysoké a konfliktní požadavky, nízká autonomie, nízká podpora, ergonomické problémy, možné násilí a pracovní rozvrh, 2. oblast stresu a fyzické zátěže - únava, napětí, mentální přetížení, potíže se spánkem a vysoká úroveň adrenalinu, 3. oblast zdraví - vysoký absentismus z důvodu nemoci a vysoké riziko poškození zdraví - oboje kvůli psychologickým, muskulo-skeletárním a kardiovaskulárním problémům.

Biggs, Dingdag a Stenson (2009) ve svém výzkumu za využití focus groups identifikovali několik důležitých témat, která mají vliv na míru stresu a únavy u řidičů autobusů městské dopravy, a těmi jsou: podpora ze strany managementu, prodej jízdenek, interakce s pasažéry, ergonomie kabiny, napjaté jízdní řády, nepravidelné směny, prodloužené směnné cykly, interakce s ostatními dopravními účastníky a dlouhé časy dojíždění. Dhar (2008) provedl kvalitativní studii na stejné skupině indických řidičů (řidičích městských autobusů). Zjistil, že mezi nejčastější prríčiny stresu patřil časový tlak, špatný stav vozů, zvýšené znečištění ovzduší, vztahy na pracovišti, nejistota práce, nedostatek uznání a ocenění. Nejvíce zmiňovanou copingovou strategií byly volnočasové aktivity (setkání s druhými, fyzická aktivita, čas s rodinou) a činnosti, které mohou poskytnout únik od nároků práce. Jako doporučení pro snížení míry stresu autor uvádí např. trénink zaměřený na posílení pozitivních copingových strategií, podporu zdravého životního stylu a celkové zlepšení pracovního prostředí. Pro úplnost je třeba uvést dotazníkové šetření provedené na 648 českých řidičích dopravních podniků (Daňková et al., 2014), mezi něž patří i řridiči městských autobusů. Šetření ukázalo, že pro tyto řidiče jsou nejčastější následující stresory: cestující, dopravní provoz (ostatní řidiči, zácpy, napjatá pracovní doba), technický stav vozidel (obvykle nikoliv systematický problém, ale spíše jednorázové výrazně stresující technické výpadky vozového parku) a vedení podniku, které se za ně nepostaví nebo je sankcionuje či se nezajímá o jejich názory. Pocit nepochopení a malé podpory ze strany vedení byl obecně mezi zaměstnanci velmi silný. Součástí výzkumu byl i dotazník strategií zvládání stresu (SVF). Výsledky ukázaly, že u řidičů celkově převažovaly pozitivní strategie při zvládání stresových situací. Mezi nejčastější zvládací strategie patřila kontrola (sebekontrola nebo kontrola situace samotné), pozitivní sebeinstrukce (pozitivní př́stup, sebemotivace, dodávání odvahy, že situaci zvládnou), vyhýbání se se stresové situaci (nebo jejím důsledkům), odmítání viny a podhodnocení.

Působící stresory mají negativní důsledky na psychickou stránku řidičů a s tím související kvalitu řízení (riskantní versus bezpečné řízení). V této souvislosti zjistil Machin (2001) ve svém výzkumu, že únava u řidičů dálkových autobusů přispívá jak k řadě krátkodobých efektů, jakými jsou redukovaná bdělost, nevyrovnané řízení, vzrušivost, fyzický diskomfort, 
tak k řadě dlouhodobých důsledků, jako je malá duševní pohoda, nedostatečné pracovní uspokojení a velké množství fyzických symptomů (bolesti zad, potíže se spánkem, bolesti hlavy a unavitelnost). Řidiči v této studii referovali, že k jejich únavě přispívaly délka pracovních směn a jejich množství, nedostatečné vybavení autobusů, malý komfort při řízení, nedostatek adekvátní přípravy, obtíže s dopravní infrastrukturou, nemoci, rodinné záležitosti a přepravovaný náklad. Jako podpůrné efekty pro prevenci stresové zátěže a únavy uváděli zastavení autobusu pro nadýchání se čerstvého vzduchu, jídlo, nápoje, poslouchání hudby, dostatečný odpočinek od řízení, kontakt s pasažéry a procházení se o přestávkách. Chen a Kao (2013) ve své studii u taiwanských městských řidičů autobusů zjistili vztah mezi syndromem vyhoření a riskantními zpo̊soby řidičského chování (např. porušování předpisů, chyby, bezohlednost) spolu s vyskytujícími zdravotními problémy. Dále pak prokázali, že vztah mezi každodenními obtížemi (tzv. hassles) a syndromem vyhoření je moderován používanými copingovými strategiemi - zatímco coping „sebekritika“ negativní projevy syndromu vyhoření v souvislosti s vyskytujícími se obtížemi zvyšuje, strategie „přehodnoceni““ a „konfrontativní“ coping projevy syndromu vyhoření snižují.

Od řidiče se očekává nejen to, že bude jezdit bezpečně, ale také zároveň že bude dodržovat jízdní řád a bude př́ijemný v kontaktu s pasažéry, což lze označit za vysoké a současně konfliktní požadavky. Meijman a Kompier (1998) provedli výzkum, ve kterém zjistili, že u řidičů městských autobusů existují požadavky týkající se kontaktu s pasažéry, dodržení jízdního řádu a bezpečnosti. Jestliže řidič preferuje vstřícný př́stup k pasažérům (v rámci výzkumu to bylo $88 \%$ řidičů), pak často nemůže zcela dodržet jízdní řád, což často zvládají řidiči opačného typu (v rámci výzkumu 13-27 \%), kteří naopak preferují psychologický distanc od pasažérů a nezabývání se jejich požadavky. Dalším konfliktním požadavkem na řidiče kladeným je přesné dodržování jízdních řádů, o což se snažilo 50 \% řidičů ve srovnání s další skupinou řidičů (30 \%), která jízdu načas nepovažovala za důležitou. Časové požadavky jsou mnohdy v rozporu s bezpečnou jízdou - autoři zjistili, že řidiči mají bud' tendenci dodržovat jízdní řády (a pak věnují méně pozornosti dodržování předpisů a bezpečné jízdě) nebo preferují bezpečnou jízdu, a pak nekladou takový důraz na precizní dodržování jízdních řádů. Dodržování jízdních řádů a časový tlak je u řidičů spojen s psychosomatickými obtížemi, muskuloskeletárními onemocněními a vyšší vnímanou pracovní zátěží a lze říct, že se jedná o nezdravý postoj ve srovnání s preferencí bezpečné jízdy navzdory jízdnímu řádu, kterou lze ohodnotit jako zdravý způsob zvládání.

Stresová zátěž u řidičů se projevuje i ve fyziologických procesech. Ve svém výzkumu, kterého se zúčastnilo 60 řidičů autobusu z Los Angeles, zjistili výzkumníci vztah mezi stresovou zátěží a zdravotními důsledky (Evans \& Carrère, 1991). Výsledky nap̌r. ukazují, že dopravní zácpa byla signifikantně spojena se zvýšením adrenalinu a noradrenalinu v moči. Dále byl zjištěn signifikantní vztah mezi vnímanou pracovní kontrolou a katecholaminy v moči. Jiná studie provedená na 210 indických řidičích autobusu (Taklikar, 2016), kteří vyplňovali dotazník zdravotních obtíží v souvislosti se stresem, prokázala, že $24 \%$ trpělo hypertenzí, $52 \%$ dyspepsií a regurgitací a 79 \% bolestí zad, přičemž míra nemocnosti se zvyšovala úměrně se zvyšující se mírou zaměstnaneckého stresu. Lze shrnout, že řidiči vykazují zvýšenou míru kardiovaskulárních, muskuloskeletárních a gastrointestinálních onemocnění (Kompier, 1996). 
$\mathrm{Na}$ základě výše uvedených výzkumů lze shrnout, že řada stresorů se projevuje u všech podskupin řidičů autobusů. Tyto stresory lze kategorizovat do několika skupin. První z nich je oblast zvládání dopravního provozu v podobě náročných dopravních situací, druhou z nich je oblast související se samotným vozidlem (v podobě technických obtíží nebo samotné ergonomie kabin a malého komfortu při ř́zení). Třetí významnou oblastí je oblast pasažérů a nároků s nimi spojených (prodej jízdenek, interakce s pasažéry, řešení konfliktních situací na zastávkách nebo při samotné jízdě). Čtvrtá oblast souvisí s organizací práce v podobě časového rozvrhu, dodržování jízdních řádů a s tím souvisejícím časovým tlakem a nepravidelnými směnami. Poslední důležitou oblastí je oblast vedení firem a toho, jakým způsobem přistupují ke svým zaměstnancům, hodnotí je a oceňují.

Co se týče stresorů specifických pro jednotlivé podskupiny řidičů autobusů, pak lze uvést, že pro řidiče autobusů městské dopravy je typické, že se musí vyrovnávat s hustým městským provozem a velkým pohybem lidí, jak v okolí zastávek, tak v samotném vozidle. Jsou tak vystaveni velké informační zátěži, která souvisí se zvýšenými nároky na pozornost. Tito řidiči často řeší konfliktní situace s pasažéry, což představuje vyšší nároky na sociální interakci. Naopak nejsou tak často tak vystaveni př́mému kontaktu s cestujícími na jednotlivých zastávkách zejména v podobě prodeje jízdenek nebo kontrole jízdních dokladů, což je naopak významný stresor pro skupinu řidičů příměstské a regionální dopravy. Oproti tomu jsou řidiči autobusů dálkové přepravy (vnitrostátní nebo mezinárodní) vystaveni zejména působení stresorů v podobě monotonie, dlouhých časových úseků řízení, velkých vzdáleností a nepravidelných pracovních směn, které vedou k zvýšené únavě řidičů a vyšší chybovosti při ř́zení.

\section{Preventivní opatření a protistresové programy}

Stres má vliv na řidičský výkon a s tím související potencionální vznik nehody, a proto jsou žádoucí preventivní programy a intervence zaměřené na jeho redukci. Studie zaměřené na evaluaci protistresových programů u řidičů autobusů (např. Kompier, Van den Berg, \& Siegrist, 2000) potvrzují, že tyto intervence vedou ke snížení míry stresu u řidičů, množství absencí a fluktuace zaměstnanců, zlepšení zdravotního stavu, psychické pohody, spokojenosti pracovníků a snížení finančních ztrát. Kompier (1996) shrnuje, že v rámci prevence a intervence mohou být protistresová opatření zaměřená bud' na změnu pracovního prostředí a pracovních situací, nebo na proškolení zaměstnanců $\mathrm{v}$ technikách zvládání stresu nebo dovedností pro redukci stresu. Uvádí tři hlavní strategie prevence stresu: 1. eliminovat nebo modifikovat situace vytvářející stres nebo dostat jedince z jejich vlivu; 2. přizpůsobit organizaci práce a pracovní zázemí individuálním charakteristikám zaměstnance; 3. posílit osobní odolnost vůči stresu, např. pomocí fyzických cvičení, meditačních nebo relaxačních technik. Mezi opatření na redukci stresu týkající se prostředí lze zařadit oblast ergonomie, která zahrnuje doporučení pro zvýšení komfortu řidiče při řízení, uspořádání směn s pravidelným odpočinkem a bez přesčasů, dostatečné přestávky, styl managementu a sociální prostředí. Mezi opatření týkající se jedince, patří formy reedukace a tréninku, jež jsou zaměřené např. na nácvik zvládání stresu, jednání s pasažéry, zvýšení úrovně fyzické aktivity apod. (Kompier, 1996). 
Právě tato oblast, a to posílení osobní odolnosti vůči stresu, je z našeho úhlu pohledu klíčovým tématem dopravní psychologů, a to $\mathrm{v}$ oblasti individuálního působení na řidiče např. v podobě vhodných protistresových programů nebo konzultací zaměřených na zásady duševní hygieny, zvládání emocí apod. Defenbacher (2016) v této souvislosti uvádí, že zejména u řidičů s vysokou mírou agresivity jsou efektivní intervence zaměřené na kognitivní procesy, nácvik relaxace a ovlivňování behaviorální složky nebo jejich kombinace. Dle Machina a Hoare (2008) je vhodné se u řidičů autobusů zaměřit na rozpoznání a nápravu maladaptivních copingových strategií, které mají vliv na psychickou pohodu řidičů a zdravotní stav. Dále pak je potřeba u řidičů rozvíjet a podporovat adaptivní copingové strategie, které vedou k bezpečnému řízení, jako je např. coping zaměřený na úkoly.

Cílem studie (Kompier, Van den Berg, \& Siegrist, 2000), v níž byla provedena evaluace intervenčních programů prevence stresu, bylo analyzovat intervence a preventivní akce mezinárodních autobusových společností s cílem snížit pracovní stres řidičů a absentismus $\mathrm{z}$ důvodu nemoci. Autoři provedli evaluaci 13 intervenčních programů prevence stresu dopravních firem. Většina studií, které hodnotily účinek intervencí prováděných v dopravních podnicích na řidiče, má své metodologické nedostatky, přesto lze shrnout, že tyto protistresové intervence jsou účinné. $V$ jejich důsledku dochází ke snížení míry stresu (měřeno psychofyziologickými ukazateli), snížení počtu absencí v souvislosti s nemocemi a mají pozitivní vliv i na subjektivní ukazatele, jakými je pocit zdraví, well-being a spokojenost. Na základě evaluace autoři shrnují, že nejúspěšnější preventivní programy v sobě zahrnují opatření zaměřené na pracovní podmínky (pracovní organizace, ergonomie, regulace práce a odpočinku, sociální pracovní opatření, styl managementu, technické intervence v dopravním prostředí) a intervence zaměřené na osobu (např. trénink řidičů) (Kompier et al., 2000). Shodně s tím Montoro et al. (2018) ve svém výzkumu zjistili, že u řidičů je třeba intervencí zacílených na zvládání emocí vyvolaných stresem, dále pak upravit pracovní podmínky, které mají jako důsledek riskantní řízení (např. pracovní přesčasy, práce na směny, vysoké požadavky pasažérů, nízká možnost kontroly práce, nízká sociální a firemní podpora, podmínky ve vozidlech, chabá dopravní infrastruktura). V oblasti uspořádání vnějšího prostředí s cílem minimalizovat působící stresory Evans, Johansson a Rydstedt (1999) ověřovali intervence, kdy na jedné autobusové lince ve Stockholmu byla vytvořena opatření snižující míru tzv. „on-the-job hassles“ (pracovní zátěže a obtíží), jakými jsou např. přednostní pruhy pro autobusy, minimalizace počtu složitých zatáček a úzkých míst, elektronické tabule informující pasažéry o zastávkách, přičemž míra zátěže byla hodnocena nezávislými pozorovateli před a po jejich zavedení. Výsledky ukázaly, že množství zátěže se u řidičů na experimentální lince snížilo oproti období před zavedením úprav, současně klesl např. i jejich systolický krevní tlak a tep. Celkově se snížila vnímaná míra stresu i oproti kontrolní skupině, která jezdila na stále stejné (neupravené) lince. Lze tedy předpokládat, že pokud snížíme míru zátěže, která působí na řidiče, klesne míra prožívaného stresu.

$\mathrm{Na}$ základě výše uvedeného lze shrnout, že v rámci preventivních opatření je třeba pracovat individuálně $\mathrm{s}$ řidičem směrem k zvýšení jeho odolnosti vưči stresu, ale také vhodným způsobem uspořádat vnější prostředí a upravit podmínky, které na něj pưsobí. Jedině takový celostní přístup podpoří to, že řidiči autobusů budou moci zodpovědně a spolehlivě vykonávat 
svoji profesi. Ideální cestou se zdá být navrhnout opatření vždy pro určitou skupinu řidičů autobusů $\mathrm{v}$ daném městě a $\mathrm{v}$ dané firmě - kličové je zanalyzovat to, jaké stresory řidiči uvádějí jako významné, posoudit dopravní prostředí v němž se řidiči pohybují (z hlediska informační zátěže a uspořádání dopravního prostředí) a použít obecné znalosti o stresorech typických pro danou skupinu řidičů. Na tomto základě je pak možné navrhnout řešení dané situace přizpůsobené konkrétní skupině řidičů, navrhnout opatření pro změnu, event. aplikovat program pro podpoření duševního zdraví řidičů.

\section{Př́klady programů na redukci stresu}

Machin (2001) navázal na Matthewsovy copingové styly při zvládání řidičského stresu a rozpracoval tréninkový program pro zvládání stresu a únavy pro řidiče autobusu. Tento program zahrnoval situační cvičení, která se prímo vztahovala $\mathrm{k}$ práci řidičů dálkových autobusů. Jejich účelem bylo identifikovat copingové styly řidičů a naučit je využívat efektivnější copingové strategie. Pro program byl mimo jiného vytvořen pracovní sešit skládající se z několika částí: První část obsahovala postup na identifikaci řidičova copingového stylu; další set cvičení byl navržen pro osvojení si rozlišování mezi pěti copingovými styly; finální část byla zaměřena na plánování efektivního zvládání obtížných a stresujících pracovních situací. Programu se účastnilo 17 vybraných řidičů. Na úvod řidiči vyplnili čtyři cvičení pro zjištění jejich copingového stylu. Pak obdrželi 4 scénáře a jejich úkolem bylo si po jejich přečtení představit, že se to stalo jim, a napsat, „,o by si mysleli, jak by se cítili a co by udělali“. Toto cvičení vedlo řidiče k uvědomění toho, jak hodnotí situaci a jak jejich hodnocení ovlivňuje intenzitu emocí a výběr copingového stylu. Potom měli za úkol generovat různé odpovědi založené na pěti copingových stylech jako reakci na čtyři nové situace. Na závěr dostali řidiči za úkol vymyslet náročnou situaci, která by se mohla odehrát během následujících čtyř týdnů, a vytvořit efektivní způsoby jejího zvládání. Všichni řidiči se zúčastnili sezení po čtyřech týdnech od ukončení programu a diskutovali o událostech, ke kterým od té doby došlo, jak na ně reagovali a jestli využili dovednosti, které se naučili v kurzu. Mnoho řidičů informovalo, že jim program pomohl být si více vědomi, jak reagují na různé obtížné pracovní situace. Evaluace efektu po delší době byla provedena telefonicky po 10 - 12 měsících od ukončení tréninku. Výsledky ukazují, že kurz a materiály byly relevantní, množství zpětné vazby dostatečné, mohlo však být poskytnuto více možností k procvičování dovedností. Většina řidičů se cítila připravena po tréninku jen lehce až mírně na problémy, které se mohou $\mathrm{v}$ budoucnosti vyskytnout. Někteří to zdůvodňovali tím, že se pro vyrovnávání s pracovními problémy cítili kompetentní již před absolvováním kurzu.

Řada tréninkových programů pro komerční řidiče se zaměřuje na provedení změn v oblasti zdraví a zdravého životního stylu s cílem efektivního způsobu práce a posílení bezpečných způsobů řízení. Krueger, Brewster, Dick, Inderbitzen a Staplin (2007) uvádějí dva př́klady tréninků pro profesionální řidiče:

1. Gettin' in Gear Wellness Programm (Roberts \& York, 2000): Tento program byl navržen pro řidiče autobusů a nákladních vozidel. Mezi základní myšlenky programu patří to, že zdravý životní styl souvisí s bezpečným řidičským chováním, a proto je řidičovo zdraví důležité pro 
pozorné řízení a bezpečnost na silnicích. Hlavními pilíři kurzu bylo zlepšení stravovacích návyků a fyzické kondice prostřednictvím pravidelného cvičení, zvýšení povědomí o důležitosti vztahů a dopadů stresu, zdraví a výkonnosti na práci, nácvik relaxace, rozpoznání reakcí na stresory a jejich modifikace, osvojení si technik zmírnění stresu a zvládání agrese na silnicích. Témata diskutovaná v kurzu byla např. kouření, obezita/nadváha, hypertenze, špatné stravovací návyky, špatná dieta a výživa, alkohol, drogy a jiné chemické substance, nedostatek fyzické aktivity/fyzického cvičení, psychologický stres a mentální trénink.

2. Řidiči jako „atleti na silnicích“ (www.occupationalathletics.com): Jednalo se o interaktivní program zaměřený na zdraví a trénink bezpečnosti, který byl zaměřen na řidiče autobusů. Účastníci si měli sami sebe představit jako atlety, jejichž hřištěm je silnice a každý den se tzv. účastní „nové hry“ s novou př́íležitostí dosáhnout osobních zdravotních a bezpečnostních cílů. Řidiči dostali audio-CD obsahující motivační rozhovor a diskusi mezi řidiči autobusů/kamionů a bezpečnostních expertů se zaměřením na životní styl a bezpečnost profesionálních řidičů, dále pak obdrželi knihu s lekcemi pro každý měsíc s cílem usnadnit jim životní změny v oblasti jejich vlastního zdraví a bezpečnosti. Lekce obsahovaly témata, jako jsou výživa, fyzické cvičení, redukce stresu, postoje a štěstí, zneužívání návykových látek, time-management, motivace, prevence nemocí, nadváha/obezita a relaxace. Pro oblast bezpečnosti při řízení byly hlavními tématy počasí jako podmínka při řízení, regulace řízení, bezpečnost pasažérů, prevence zranění a vztahy zaměstnavatel-zaměstnanec.

Jeden z programů pro profesionální řidiče byl navržen v souvislosti s tzv. modelem úsilí a zisku (ERI - Effort-reward imbalance model) (Siegrist, 1996), který identifikuje situační a osobnostní charakteristiky vedoucí $\mathrm{k}$ chronickému stresu v př́ípadě, když jsou pracovní požadavky vysoké (stanovené vnější autoritou nebo na základě vnitřních impulsů zaměstnance v podobě velkého pracovního nasazení) a naopak je nízký zisk (např. v podobě platu, ocenění a prestiže). Pilotního programu (Aust, Peter, \& Siegrist, 1997) se zúčastnilo 54 řidičů městské autobusové dopravy, kteří absolvovali 12ti-týdenní kurzu zvládání stresu založeného na ERI modelu. Intervence zahrnovaly relaxaci, zvládání vzteku a nadměrného pracovního nasazení, management konflikti̊ s nadřízenými a doporučení pro strukturální změny v práci. Po 12 týdnech byla průměrná úroveň ,,potřeby kontroly“ (kritický, pro zdraví neblahý styl zvládání pracovních požadavků) signifikantně redukovaná a tento efekt přetrvával i po 3 měsících. Lze shrnout, že program zvládání stresu založený na této teorii vykazuje pozitivní vliv na psychický stav řidičů. Vliv ocenění (reward), nadměrného pracovního nasazení (overcommitment) na psychické a fyzické zdraví v souvislosti se Siegristovým modelem potvrdili i Tse, Flin a Mearns (2007), kteří zjistili, že pro snížení míry zátěže řidičů je potřeba jim dávat najevo ocenění (např. projevovat, že mají pro podnik hodnotu, zvýšit jim plat nebo jim dát možnost se profesně rozvíjet). Zároveň je žádoucí věnovat pozornost těm řidičům, kteří mají tendenci k nadměrnému pracovnímu nasazení, jež vede ke zhoršenému zdraví, a pomáhat jim najít rovnováhu mezi prací a dalšími aktivitami. A konečně pak redukovat ty zátěžové vlivy, které vedou k únavě a přetěžování řidičů. 
V České republice byl v letech 2012-2014 realizován projekt „Stres a jeho zvládání u řidičů městské hromadné dopravy“, jehož cílem bylo zmapovat problematiku stresu u řidičů dopravních podniků a následně navrhnout a realizovat protistresový program. Výzkumná část projektu byla jak kvalitativní (individuální hloubkové rozhovory a focus groups), tak kvantitativní (dotazníkové šetření). Jedním z výsledků projektu bylo vypracování metodiky protistresového programu (Zámečník et al., 2014), kterou mohou dopravní podniky využívat pro prevenci stresu u svých zaměstnanců. Časová dotace kurzů je variabilní - lze zvolit 1-denní až 5-denní školení. Moduly školení jsou zaměřené na teoretická témata (definice stresu, fáze stresu a jeho projevy), zvládání konkrétních stresových situací, relaxaci a zdravý životní styl. Metodika byla ověřena v pilotním programu (Kurečková, Paráková, Winklerová, \& Brummerová, 2014), kterého se zúčastnilo 58 řidičů z Dopravního podniku města Brna. Ti byli rozděleni do 6 skupin v období březen - ř́jen 2014. Kurz probíhal jako jednodenní setkání v délce 8 hodin. Program byl zaměřen na identifikaci nejsilněji vnímaných příčin stresu a aktuální problémy, nejčastější stresující situace a nácvik řešení, relaxační techniky a pozitivní aspekty práce řidiče. Po absolvování kurzu byli řidiči dotázáni na subjektivní hodnocení př́nosu kurzu pro jejich život. $97 \%$ účastníků hodnotilo kurz jako prínosný a obohacující pro ně samotné, z toho 28 \% prohlásilo, že bude určitě používat techniky a znalosti obsažené v kurzu i v praktickém životě. Mezi návrhy na zlepšení obsahu kurzu se objevil návrh na zařazení videoukázek zaměřených na řešení jednotlivých situací (problémů v zaměstnání nebo s cestujícími) a opakování kurzu 1x za 2 roky. Řidiči by dále rádi do kurzu zařadili témata týkající se jednání s cestujícími, praktických záležitostí v dopravě, péče o zdraví řidičů, popřípadě zásady první pomoci.

Jak je patrné, ve světě i v ČR existují snahy o to vytvořit preventivní programy zaměřené na zvýšení odolnosti řidičů vůči stresu. Ukazuje se však, že toto téma je velmi komplexní a řada navržených programů je zaměřena na prevenci v podobě poskytování informací k tomuto tématu. Je otázkou, nakolik pak řidiči dokážou nabyté poznatky využít v praxi. Ukazuje se, že je důležité řidiče $v$ rámci programu aktivně zapojit, podpořit jejich výuku zajímavými materiály a dát jim dostatek možností získané poznatky a dovednosti aplikovat v praxi. Důležitá je i časová dotace v podobě několika měsíců, jelikož jakákoli změna chování potřebuje delší časový úsek, a poskytnout i supervizi, která zajistí zpětnou vazbu a podporu v rámci zaváděných změn. Na základě naší zkušenosti je důležité při vytváření preventivních programů stanovit konkrétní cíle a zaměřit daný program na jedno specifické téma, to důkladně objasnit, řidiče v něm proškolit a dostatečně natrénovat nové dovednosti. Jako perspektivní se v této oblasti, i na základě zahraničních výzkumů, ukazuje zaměřit pozornost na pojem coping a nácvik adaptivních copingových stylů. Pozitivní se také jeví učit řidiče zacházet s emocemi (zejména vztekem), zvládat konflikty a používat prvky duševní hygieny (např. relaxační a meditační techniky).

\section{Závěr}

Studie zkoumající stres u řidičů autobusů se shodují v tom, že jsou tito řidiči vystaveni vysokým požadavkům, mají nízkou možnost kontroly a nedostává se jim dostatečné podpory. Významnými stresory této profese jsou kontinuální časový tlak, mnohdy nadměrná pracovní 
zátěž, vysoká environmentální stimulace, problematická interakce s dalšími účastníky dopravního provozu, interakce s pasažéry a nedostatek sociální opory a nepravidelné směny. Lze tedy shrnout, že tato profese patří mezi zátěžové povolání. Tento fakt by měli zohledňovat jak samotní řidiči a v té souvislosti upravit svůj životní styl a věnovat zvýšenou pozornost svému zdraví a psychické pohodě, tak i firmy, které řidiče zaměstnávají. Stresová zátěž má negativní dopad na psychické a fyzické zdraví řidičů a projevuje se ve zvýšené nemocnosti řidičů, což má své socioekonomické důsledky. Pracovní stres těchto řidičů je jedním z faktorů, který může vést k riskantnímu dopravnímu chování a v jeho důsledku ke vzniku dopravní nehody.

V této studii jsme uvedli řadu opatření, které je třeba zavádět pro to, aby se snížila míra stresové zátěže u těchto řidičů. Jak ukazují zahraniční studie, je vhodné aplikovat opatření na snížení dopadu stresu u této profese, která mohou být jak v podobě změny vnějších pracovních podmínek včetně uspořádání dopravního prostředí směrem k snížení stresujících faktorů, tak v podobě opatření, která vedou řidiče k vyšší odolnosti vůči stresu. Dosud realizované programy a provedená preventivní opatření ukazují jejich pozitivní vliv na psychickou pohodu řidičů a jejich zdravotní stav. Většina provedených preventivních programů je zahraničních. V České republice byl však již také realizován pilotní projekt pro zmapování stresu u řidičů dopravních podniků a následně navržena metodika antistresového programu. Do budoucna by bylo vhodné toto téma dále rozpracovat a navrhnout dlouhodobější, pro řidiče atraktivní a prakticky orientované programy na redukci stresu, v nichž by si řidiči osvojili zásady duševní hygieny a zdravého životního stylu, a následně sledovat jejich efektivitu v dlouhodobém horizontu. Žádoucí je také zjišt'ovat, jaké stresory jsou pro řidiče zátěžové a navrhovat cílená opatření. Př́nosné je pracovat s pojmem „coping“, edukovat řidiče v této oblasti a učit je reagovat v zátěžových situacích efektivněji s cílem zmírnit vnímanou míru stresu.

Kromě praktických opatření zaměřených na snížení míry pưsobící stresové zátěže a zvýšení odolnosti řidičů vůči stresu je potřeba zdůraznit i potřebu systémového řešení této otázky. Lze říci, že problematika stresu a jeho řešení spočívá v současnosti na dobrovolné bázi a firmy se mohou rozhodnout, jestli budou či naopak nebudou řešit psychické a fyzické zdraví řidičů a podmínky práce směrem $\mathrm{k}$ minimalizaci působících stresorů. V současné chvíli je systém práce řidičů upraven zákoníkem práce, jehož dodržování by mělo zajistit kvalitní pracovní podmínky. Neexistuje však systém péče o psychické zdraví řidičů např. v podobě implementace protistresových programů, který by byl legislativně zakotven. To souvisí nejspíše s tím, že široká veřejnost nevnímá tento problém jako klíčový. Do budoucna je potřeba této problematice věnovat pozornost a uvažovat o možnostech, jak se mu systémově věnovat tak, aby toto zodpovědné povolání dostalo náležitou podporu, která bude mít ekonomické a společenské dopady (např. v podobě snížení nemocnosti řidičů, zvýšení bezpečného dopravního chování a snížení nehodovosti, zvýšení komfortu cestování apod.).

Na závěr je třeba zmínit jednu z organizací, v níž se mohou sdružovat dopravní psychologové, a tou je Asociace dopravních psychologů ČR. Ta svými podněty kladně přispívá ke zvýšení bezpečnosti silničního provozu, zejména $\mathrm{v}$ oblasti psychologického výběru osob do profesí řidičů převážejících osoby, náročnou techniku či nebezpečné zboží. Preventivní působení na 
profesionální řidiče je jedním z jejích možných dílčích zájmů. Pro úplnost je třeba uvést systém akreditací Ministerstva dopravy ČR pro provádění dopravně-psychologických vyšetření, který svými uzákoněnými akreditačními požadavky zajišt’uje to, že budou dopravně-psychologická vyšetření prováděna dopravními psychology při výběru profesionálních řidičů erudovaně a s ohledem na typ vykonávané řidičské praxe.

\section{Poděkování}

Tento článek byl vytvořen za finanční podpory Ministerstva školství, mládeže a tělovýchovy v rámci programu Národní program udržitelnosti I, projektu Dopravní VaV centrum (LO1610) na výzkumné infrastruktuře pořízené z Operačního programu Výzkum a vývoj pro inovace (CZ.1.05/2.1.00/03.0064).

\section{Literatura}

Aust, B., Peter, R., \& Siegrist, J. (1997). Stress management in bus drivers: A pilot study based on the model of effort-reward imbalance. International Journal of Stress Management, 4(4), 297-305. https://doi.org/10.1023/B:IJSM.0000008709.11196.19

Biggs, H., Dingdag, D., \& Stenson, N. (2009). Fatigue factors affecting metropolitan bus drivers: A qualitative investigation. Work, 32(1), 5-10. https://doi.org/10.3233/WOR-2009-0810

Coon, E. M., Blonk, R. W. B., de Zwart, B. C. H, Frings-Drese, M. H. W., \& Broersen, J. P. J. (2002). Job stress, fatigue, and job dissatisfaction in Dutch lorry drivers: towards an occupation specific model of job demands and control. Occupational and Environmental Medicine, 59(6), 356-361. https://doi.org/10.1136/oem.59.6.356

Daňková, L., Havlíčková, D., Kurečková, V., Paráková, K., Snopek, M., Šimeček, M., ...Zámečník, P. (2014). Analýza dat získaných v rámci projektu matrix. Závěrečná zpráva. Brno: Centrum dopravního výzkumu.

Deffenbacher J. L. (2016). A review of interventions for the reduction of driving anger. Transp. Res. Part F Traffic Psychol. Behav., 42(2), 411-421. https://doi.org/10.1016/j.trf.2015.10.024

De Lange, A. H., Kompier, M. A., Taris, T. W., Geurts, S. A., Beckers, D. G., Houtman, I. L., \& Bongers, P. M. (2009). A hard day's night: A longitudinal study on the relationships among job demands and job control, sleep quality and fatigue. Journal Sleep Research, 18(3), 374383. https://doi.org/10.1111/j.1365-2869.2009.00735.x

Dhar, R. L. (2008). Quality of work life: A study of municipal corporation bus drivers. The Journal of International Social Research, 2(6), 251-273. https://doi.org/10.1504/IJICBM.2009.027181

Dorn, L., Stephen, L., Af Wåhlberg, A., \& Gandolfi, J. (2010). Development and validation of a self-report measure of bus driver behaviour. Ergonomics, 53(12), 1420-1433. https://doi.org/10.1080/00140139.2010.532882

Evans, G. W., \& Carrère, S. (1991). Traffic congestion, perceived control and psychological stress among urban bus drivers. Journal of Applied Psychology, 76(5), 658-663. https://doi.org/10.1037/0021-9010.76.5.658

Evans, G. W., Johansson, G., \& Rydstedt, L. (1999). Hassles on the job: a study of a job intervention with urban bus drivers. Journal of Organizational Behavior, 20(2), 199-208. https://doi.org/10.1002/(SICI)1099-1379(199903)20:2<199::AID-JOB939>3.0.CO;2-I

Horáková, M. (2009). Výzkum strategií zvládání stresu a jejich vztah k dalším charakteristikám u řidičů záchranné služby. E-psychologie, 3(2), 10-21. Dostupné z https://epsycholog.eu/pdf/horakova.pdf 
Chen, C. F., \& Kao, Y. A. (2013). The connection between the hassles-burnout relationship, as moderated by coping, and aberrant behaviors and health problems among bus drivers. Accident Analysis and Prevention, 53(1), 105-111. https://doi.org/10.1016/j.aap.2013.01.004

Karasek, R. A. (1979). Job demands, job decision latitude, and mental strain: implications for job redesign. Administrative Science Quarterly, 24(2), 285-309. https://doi.org/10.2307/2392498

Kompier, M. A. (1996). Bus drivers occupational stress and stress prevention. Geneva: International Labour Organization. Dostupné z http://www.ilo.int/wcmsp5/groups/public/--ed_protect/---protrav/---safework/documents/publication/wcms_250105.pdf

Kompier, M. A. J., Aust, B., Van den Berg, A. M., \& Siegrist, J. (2000): Stress prevention in bus drivers: Evaluation of 13 natural experiments. Journal of Occupational Health Psychology, 5(1), 11-31. https://doi.org/10.1037/1076-8998.5.1.11

Krueger, P. G., Brewster, R. M., Dick, V. R., Inderbitzen, R. E., \& Staplin, L. (2007). Health and wellness programs for commercial drivers. Washington, DC: The National Academies Press. https://doi.org/10.17226/23161

Kühlmann, T. M. (1990). Coping with occupational stress among urban bus and tram drivers. Journal of Occupational Psychology, 63(1), 89-96. https://doi.org/10.1111/j.20448325.1990.tb00512.x

Kurečková, V., Paráková, K., Winklerová, L., \& Brummerová, K. (2014). Evaluace protistresových projektů. Hodnocení pilotniho běhu protistresových kurzů pro řidiče DPMB. Brno: Centrum dopravního výzkumu.

Lazarus, R. S. (1966). Psychological stress and the coping proces. New York: Mc Graw-Hill.

Lazarus, R. S., Folkman, S. (1984): Stress, appraisal and coping. New York: Springer.

Machin, A. (2001). Evaluating a non-prescriptive fatigue management strategy for express coach drivers: A report prepared for the Australian Transport Safety Bureau. Australia: University of Southern Queensland.

Machin, M. A., \& Hoare, P. N. (2008). The role of workload and driver coping styles in predicting bus drivers' need for recovery,positive and negative affect, and physical

symptoms. Anxiety, Stress \& Coping, 21(4), 359 - 375. https://doi.org/10.1080/10615800701766049

Matthews, G. (1996). Individual differences in driver stress and performance. Human Factors and Ergonomics Society Annual Meeting Proceedings, 40(12), 579-583. https://doi.org/10.1177/154193129604001205

Matthews, G., Desmond, P. A., Joyner, L., Carcary, B, \& Gilliland, K. (1996). Validation of the driver stress inventory and driver coping questionnaire (Paper presented at the International Conference on Traffic and Transport Psychology). Valencia, Spain.

Matthews, G., \& Desmond, P. A. (1998). Personality and multiple dimensions of task induced fatigue: a study of simulated driving. Personality and Invididual Defferences, 25(3), 443-458. https://doi.org/10.1016/S0191-8869(98)00045-2

Matthews, G., Dorn, L., Hoyes, T. W., Davies, D. R., Glendon, A. I., \& Taylor, R. G. (1998). Driver stress and performance on a driving simulator. Human Factors, 40(1), 136-149. https://doi.org/10.1518/001872098779480569

Matthews, G. (2001). A transactional model of driver stress. In P. A. Hancock \& P. A. Desmond (Eds.), Stress, workload, and fatigue (s. 133-163). New Jersey: Lawrence Erlbaum Associates.

Matthews, G. (2002). Towards a transactional ergonomics for driver stress and fatigue. Theoretical Issues in Ergonomic Science, 3(2), 195-211. https://doi.org/10.1080/14639220210124120

Meijman, T. F., \& Kompier, M. A. J. (1998). Bussy business: How urban bus drivers cope with time pressure, passengers, and traffic safety. Journal of Occupational Health Psychology, 3(2), 109-121. https://doi.org/10.1037/1076-8998.3.2.109 
Montoro, L., Useche, S., Alonso, F., \& Cendales, B. (2018). Work environment and driving anger: a structural equation model for predicting traffic sanctions of public transport drivers. International Journal of Environmental Research and Public Health, 15(3), 497-509. https://doi.org/10.3390/ijerph15030497

Öz, B., Özkan, T., \& Lajunen, T. (2010). Professional and non-professional drivers's stress reactions and risky driving. Transportation Research Part F: Traffic Psychology and Behaviour, 13(1), 32-40. https://doi.org/10.1016/j.trf.2009.10.001

Roberts, S., \& York, J. (2000). Design, development and evaluation of truck and bus driver wellness programs: Final Report. Washington: Federal Motor Carrier Safety Administration. Dostupné z https://rosap.ntl.bts.gov/view/dot/30020

Sarason, I. G., Sarason, B. R., Keefe, D. E., Hayes, B. E., \& Shearin, E. N. (1986). Cognitive interference: Situational determinants and traitlike characteristics. Journal of Personality and Social Psychology, 51(1), 215-226. https://doi.org/10.1037/0022-3514.51.1.215

Siegrist, J. (1996). Adverse health effects of high effort - low reward conditions at work. Journal of Occupational Health Psychology, 1(1), 27-43. https://doi.org/10.1037/1076-8998.1.1.27

Taklikar, C. S. (2016). Occupational stress and its associated health disorders among bus drivers. International Journal of Community Medicine and Public Health, 3(1), 208-211. https://doi.org/10.18203/2394-6040.ijcmph20151564

Tse, J. L. M., Flin, R., \& Mearns, K. (2007). Facets of job effort in bus driver health: Deconstructing „effort“ in the effort-reward imbalance model. Journal of Occupational Health Psychology, 12(1), 48-62. https://doi.org/10.1037/1076-8998.12.1.48

Zámečník, P., Kurečková, V., Řezáč, P., Snopek, M., Daňková, L., Paráková, K., \& Winklerová, L. (2014). Metodika protistresového skupinového programu pro řidiče MHD. Brno: Centrum dopravního výzkumu.

\section{O autorce}

Mgr. Miroslava Horáková ukončila v roce 2006 studium psychologie na FF MU Brno. Nyní pracuje v Centru dopravního výzkumu v. v. i. v Oblasti dopravní psychologie. Mezi její profesní zájmy patř́ problematika mladých řidičů, řidičský stres, rehabilitační programy pro rizikové řidiče a protistresové programy pro profesionální řidiče.

Kontaktní údaje:

Adresa: Centrum dopravního výzkumu, v. v. i., Líšeňská 33 a, 63900 Brno, tel. 541641244 Email: miroslava.horakova@cdv.cz

Horáková, M. (2020). Stres u profesionálních řidičů se zaměřením na řidiče autobusů, preventivní opatření a protistresové programy. E-psychologie, 14(1), 39-54. https://doi.org./10.29364/epsy.365 